\title{
Glycerol restores p53-dependent radiosensitivity of human head and neck cancer cells bearing mutant p53
}

\author{
K Ohnishi, I Ota*, A Takahashi and T Ohnishi \\ Departments of Biology and *Otorhinolaryngology, Nara Medical University, 840 Shijo-cho, Kashihara, Nara 634-8521, Japan
}

\begin{abstract}
Summary Mutation or inactivation of p53 is known to be present in approximately $50 \%$ of human cancers. We propose here a novel strategy for overcoming this problem in mutant p53-targeting cancer therapies. We examined the restoration of radiation-induced p53-dependent apoptosis by a chemical chaperone (glycerol) in human head and neck cancer cells (SAS cells, showing wild-type p53 phenotype). SAS cells transfected with mutant p53 (SAS/mp53) showed radioresistance compared with SAS cells (SAS/neo) transfected with neo vector as a control, but became radiosensitive when pre-treated with glycerol before X-ray irradiation. Apoptosis in the SAS/mp53 cells was induced by X-rays with glycerol pre-treatment, but not without glycerol pre-treatment, whereas apoptosis in the SAS/neo cells was induced in both cases. Gel mobility-shift assays showed that after X-ray irradiation combined with glycerol pre-treatment, mp53 was able to bind to the sequencespecific region upstream of the bax gene regulating apoptosis. These results suggest that glycerol is effective in inducing a conformational change of p53 and restoring normal function to $\mathrm{mp} 53$, leading to enhanced radiosensitivity through the induction of apoptosis. This novel tool for enhancement of radiosensitivity in cancer cells bearing mp53 may be useful for p53-targeted radiotherapy. (C) 2000 Cancer Research Campaign http://www.bjcancer.com
\end{abstract}

Keywords: p53; apoptosis; Bax; radiosensitivity; glycerol; chemical chaperone

Wild-type p53 (wt p53) has multi-functions, including suppression of cancer initiation and tumour growth through the induction of downstream genes and/or protein interaction (Caelles et al, 1994; Dulic et al, 1994; El-Deiry et al, 1994; Waga et al, 1994). In a recent clinical report, we showed that wt 553 patients show higher survival rate after radiotherapy, resulting from Bax and Bcl-2 regulation, compared with mutated p $53(\mathrm{mp} 53)$ patients (Harima et al, 1998). To trigger the multi-functions of $\mathrm{p} 53$, p53 is required to form the correct conformation which enables p53 to bind to specific DNA sequences regulating gene expression. Mutations in the $p 53$ gene cause conformational alterations in the p53 protein, and the majority of $\mathrm{mp} 53$ proteins can no longer regulate expression of downstream genes (Bargonetti et al, 1991; Kern et al, 1991). Mp53 genes are frequently observed in human cancer cells (Hollstein et al, 1991; Jia et al, 1997). Thus, a strategy for inducing mp53 to fold correctly could be useful for cancer therapy. We have recently reported that heat stress induces WAF1 expression only when p53 protein is wtp53 using a human glioblastoma cell line (A-172, wtp53) and its transfectants with an mp53 vector (A-172/mp53) (Ohnishi et al, 1996, 1998). A-172 mp53 cells abolished heatinduced WAF1 expression due to the dominant negative nature of the mp53 protein over endogenous wtp53 (Kern et al, 1992; Unger et al, 1992). However, heat-induced WAF1 accumulation was restored in these mp53-transfected cells when the cells were pretreated with glycerol (Ohnishi et al, 1999a). Glycerol thus appeared to confer wtp53 function on mp53. The function of glycerol as a chemical chaperone has been reported elsewhere (Thomas et al, 1995; Welch and Brown, 1996). Glycerol seems to correct the

Received 15 March 2000

Revised 7 August 2000

Accepted 13 August 2000

Correspondence to: T Ohnishi conformation of some types of proteins which cause human diseases.

\section{MATERIALS AND METHODS}

\section{Cells}

Head and neck cell line of human squamous cell carcinoma, SAS cells (provided by JCRB, Tokyo, Japan) were cultured at $37^{\circ} \mathrm{C}$ in Dulbecco's Modified Eagle medium containing $10 \%(\mathrm{v} / \mathrm{v})$ fetal bovine serum, penicillin $\left(50 \mathrm{U} \mathrm{ml}^{-1}\right)$, streptomycin $\left(50 \mu \mathrm{g} \mathrm{ml}^{-1}\right)$ and kanamycin $\left(50 \mu \mathrm{g} \mathrm{ml}^{-1}\right)$ (DMEM-10) in a conventional humidified $5 \% \mathrm{CO}_{2}$ incubator.

\section{Plasmids}

SAS cells were transfected with plasmid pC53-248, which contains an mp53 gene (codon 248, from Arg to Trp) which encodes a dominant negative mp53, or with the control vector pCMV-Neo-Bam. These plasmids were provided by B Vogelstein, Johns Hopkins Oncology Center, MD, USA. The stable transfectants SAS/mp53 and SAS/neo were selected with G418 (200$400 \mu \mathrm{g} \mathrm{ml}^{-1}$, Sigma Chemical Co, St Louis, MO), and used for the present experiments. Detailed procedure for transfection is described elsewhere (Ohnishi et al, 1998).

\section{Glycerol treatment}

Cells were treated with glycerol (at final concentration of $0.6 \mathrm{M}$ ) $48 \mathrm{~h}$ before X-ray irradiation and then were incubated at $37^{\circ} \mathrm{C}$ for $10 \mathrm{~h}$ in the presence of glycerol until sampling. X-ray irradiation was performed in the presence of glycerol. In the case of cell survival assay, the medium with glycerol was changed with 
glycerol-free one after $10 \mathrm{~h}$ incubation and thereafter cells were incubated for 10 to 14 days at $37^{\circ} \mathrm{C}$ in glycerol-free medium.

\section{X-ray irradiation}

For the X-ray irradiation treatment, subconfluent cells in $25-\mathrm{cm}^{2}$ flasks containing DMEM-10 were exposed to X-rays (2.5-10 Gy) using a $150 \mathrm{kVp}$ X-ray generator (Model MBR-1520R, Hitachi, Tokyo, Japan) with a total filtration of $0.5 \mathrm{~mm}$ aluminium plus $0.1 \mathrm{~mm}$ copper filter, and then incubated at $37^{\circ} \mathrm{C}$.

\section{Cell survival assay}

To measure radiosensitivity of the cells, cell survival after X-ray irradiation was quantitated by plating cells into $25 \mathrm{~cm}^{2}$ flask containing the medium. Thereafter, cell colonies were rinsed with PBS, fixed with methanol, stained with $2 \%$ Giemsa solution (Merck, Woodbridge, NJ, USA). Colonies containing at least 50 cells were counted. The number of cells per colony was determined prior to experiments.

\section{Analysis of apoptosis}

Induction of apoptosis was analysed by detection of both DNA fragmentation and apoptotic bodies. To detect DNA fragmentation in the nucleosomal size range, cells were suspended in lysis buffer containing $10 \mathrm{mM}$ Tris-HCl, pH 7.4, $10 \mathrm{mM} \mathrm{NaCl}, 10 \mathrm{mM}$ EDTA and $1 \%$ sodium $\mathrm{N}$-lauroylsarcosinate, incubated with $100 \mu \mathrm{g} \mathrm{ml}^{-1}$ proteinase $\mathrm{K}$ at $37^{\circ} \mathrm{C}$ overnight, and then centrifuged at $18500 \mathrm{~g}$ for $30 \mathrm{~min}$. The resulting supernatants were incubated with $100 \mu \mathrm{g} \mathrm{ml}^{-1} \mathrm{RNase} A$ at $37^{\circ} \mathrm{C}$ for $1 \mathrm{~h}$. The DNA in the solution was precipitated with ethanol at $-20^{\circ} \mathrm{C}$, dissolved in $10 \mathrm{mM}$ Tris- $\mathrm{HCl}$, $\mathrm{pH} 8.0$, and $1 \mathrm{mM}$ EDTA, and electrophoresed for $30 \mathrm{~min}$ at $100 \mathrm{~V}$ through $3 \%$ NuSieve $3: 1$ gels containing $40 \mathrm{mM}$ Tris-acetate, $\mathrm{pH} 7.8,2 \mathrm{mM}$ EDTA and $0.5 \mu \mathrm{g} \mathrm{ml}^{-1}$ ethidium bromide. After electrophoresis, the gels were photographed under ultraviolet light. For detection of apoptotic bodies, cells were fixed with $1 \%$ glutaraldehyde (Nakalai Tesque, Kyoto, Japan) in PBS at $4^{\circ} \mathrm{C}$, washed with PBS, stained with $0.2 \mathrm{mM}$ Hoechst 33342 (Sigma Chemical Co), and then observed under a fluorescence microscope. At least 300 cells were counted in each experiment.

\section{Gel mobility-shift assay}

In in vivo samples, the cells (about $2 \times 10^{7}$ cells) were irradiated with X-rays (6 Gy) in the presence or absence of glycerol $(0.6 \mathrm{M})$. The nuclear extracts were prepared $6 \mathrm{~h}$ after X-ray irradiation according to the method described elsewhere (Ohnishi et al, 1998). In in vitro samples, whole cell extracts were prepared from intact cells (about $2 \times 10^{7}$ cells) and treated with glycerol $(0.6 \mathrm{M}), \mathrm{X}$-rays ( $6 \mathrm{~Gy})$ or a combination of glycerol and X-rays (6 Gy), and subsequently incubated for $30 \mathrm{~min}$ at $37^{\circ} \mathrm{C}$. The p53-p53 consensus sequence (p53CON) binding activity was measured by a gel mobility-shift assay (Ohnishi et al, 1998) using a synthetic doublestranded DNA fragment encoding the p53CON (5'-GGACATGCCCGGGCATGTCC-3', Japan Bioservice, Niiza, Saitama, Japan) based on a specific sequence located upstream of the bax gene as a probe.

\section{RESULTS AND DISCUSSION}

To examine the effect of glycerol on the radiosensitivity of SAS/mp53 and SAS/neo cells, the clonogenic surviving fractions after X-ray irradiation combined with pre-treatment with or without glycerol $(0.6 \mathrm{M})$ were measured. As shown in Figure 1, the SAS/mp53 cells were about 1.5 times more resistant to X-rays than the SAS/neo cells at the $\mathrm{D}_{10}$ dose. However, when pre-treated with glycerol, SAS/mp53 cells become about 1.5 times more Xray-sensitive at the $\mathrm{D}_{10}$ dose. Glycerol caused little enhancement of X-ray sensitivity in SAS/neo cells. On the other hand, $\mathrm{SAS} / \mathrm{mp} 53$ and SAS/neo cells treated with glycerol alone $(0.6 \mathrm{M})$ showed about $80 \%$ surviving fractions, and thus $0.6 \mathrm{M}$ glycerol appeared to cause no serious cell damage regardless of $p 53$ status. These results suggest that glycerol affects the radiosensitivity of these cells in a p53-dependent manner.

Furthermore, we examined the induction of apoptosis by detection of apoptotic bodies and DNA fragmentation to elucidate the mechanism of enhancement of radiosensitivity by glycerol in SAS/mp53 cells. We analysed the nuclear morphology with Hoechst 33342 staining. We scored the number of apoptotic bodies such as those shown by arrows in the insert of Figure 2. The incidence of apoptosis increased with time after X-ray irradiation (6 Gy) in SAS/neo cells (about $10 \%$ at $48 \mathrm{~h}$ ), while there was almost no increase in the incidence of apoptosis up to $72 \mathrm{~h}$ after

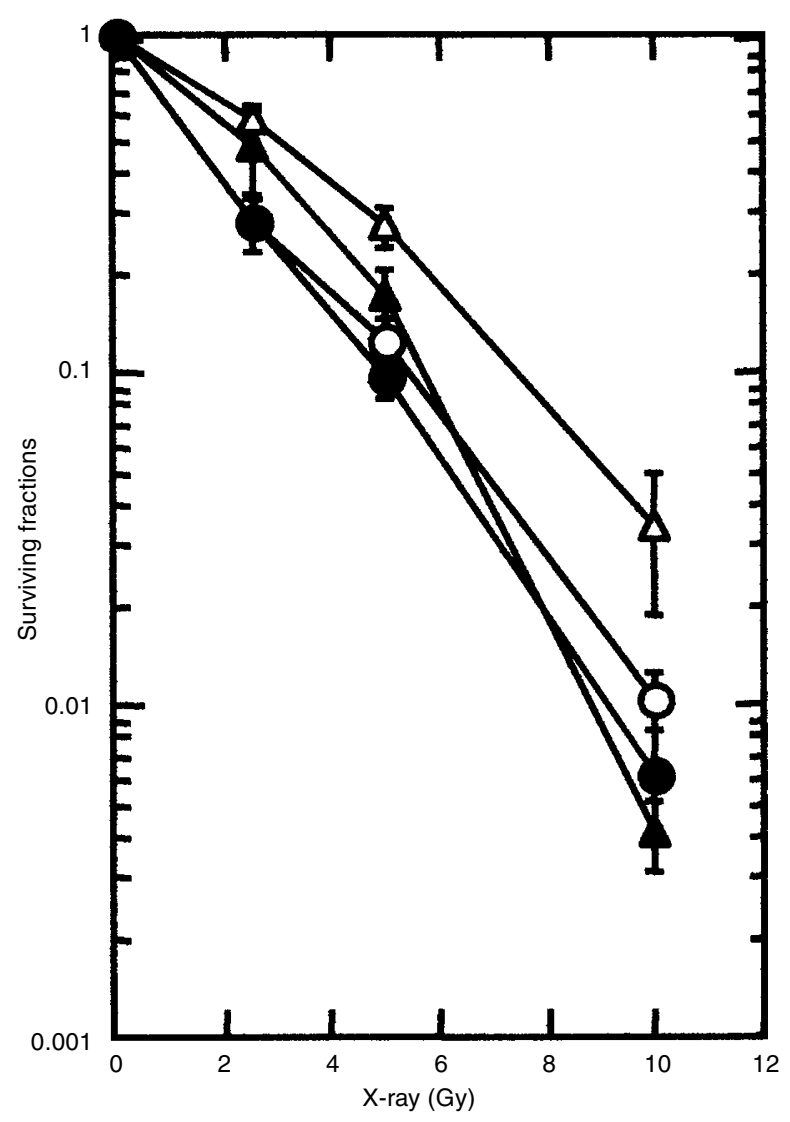

Figure 1 Clonogenic surviving fractions of transformant SAS cells after $\mathrm{X}$-ray irradiation measured by the colony formation assay. Open circles, SAS/neo cells; closed circles, SAS/neo cells pre-treated with $0.6 \mathrm{M}$ glycerol for $48 \mathrm{~h}$ before X-ray irradiation; open triangles, SAS/mp53 cells; closed triangles, SAS/mp53 cells pre-treated with $0.6 \mathrm{M}$ glycerol. Surviving fractions were measured in 3 independent duplicate experiments 


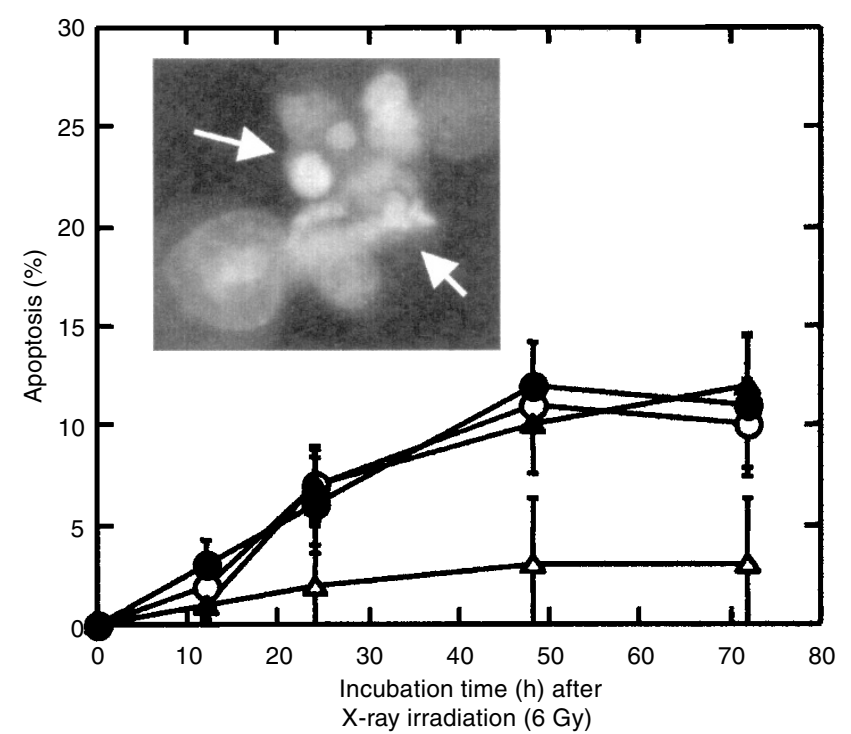

Figure 2 Apoptotic bodies detected with Hoechst 33342 staining. The cells were incubated at $37^{\circ} \mathrm{C}$ for $0,12,24,48$ or $72 \mathrm{~h}$ after X-ray irradiation (6 Gy) with or without glycerol $(0.6 \mathrm{M})$, fixed with glutaraldehyde, stained with Hoechst 33342, and then observed under a fluorescence microscope. Apoptotic bodies were counted under 3 different fields of the microscopic observation. 100 cells were judged under one field. The symbols are the same as in Figure 1. Inserted photograph, SAS/mp53 cells $48 \mathrm{~h}$ after X-ray irradiation (6 Gy) with glycerol $(0.6 \mathrm{M})$ treatment. Arrows indicate apoptotic bodies

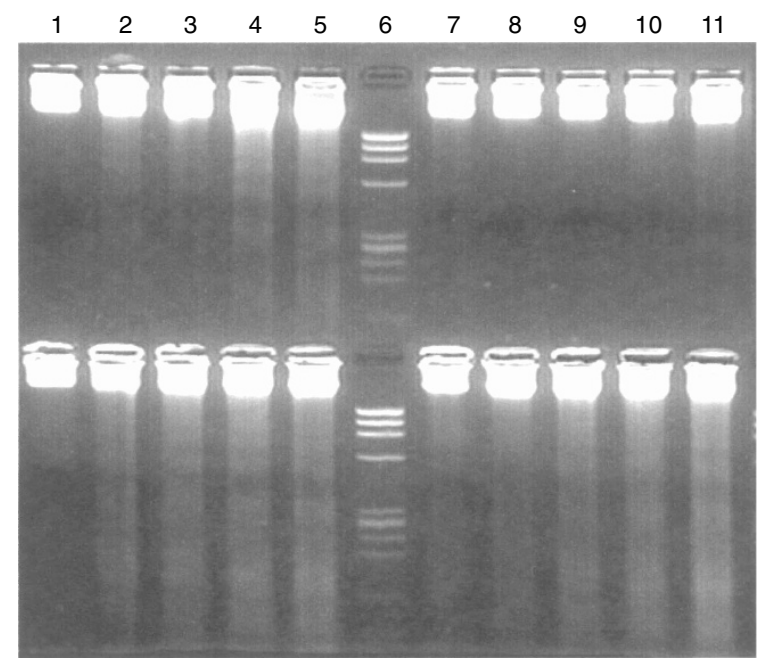

Figure 3 DNA fragmentation detected by agarose gel electrophoresis of DNA extracted from SAS/neo (lanes 1-5) and SAS/mp53 cells (lanes 7-11) after X-ray irradiation (6 Gy) (upper panel) or after X-ray irradiation (6 Gy) in the presence of $0.6 \mathrm{M}$ glycerol (lower panel). After the incubation at $37^{\circ} \mathrm{C}$ for $12,24,42$, or $72 \mathrm{~h}$, the cells were suspended in the lysis buffer to extract DNA for gel electrophoresis. Lanes 1 and 7, unirradiated; lanes 2 and 8, at $12 \mathrm{~h}$; lanes 3 and 9 , at $24 \mathrm{~h}$; lanes 4 and 10 , at $42 \mathrm{~h}$; lanes 5 and 11 , at $72 \mathrm{~h}$ after X-ray irradiation. Lane $6, \varnothing \mathrm{X} 174$ DNA Hae III fragments as size markers

X-ray irradiation in SAS/mp53 cells (about 3\%). The rate of apoptosis in SAS/neo cells was about 5-fold higher than that in $\mathrm{SAS} / \mathrm{mp} 53$ cells at $48-72 \mathrm{~h}$ after X-ray irradiation (Figure 2). When treated with glycerol $(0.6 \mathrm{M})$ before X-ray irradiation, the $\mathrm{SAS} / \mathrm{m} p 53$ cells underwent apoptosis with time after X-ray irradiation (6 Gy). The time course of X-ray-induced apoptosis in the

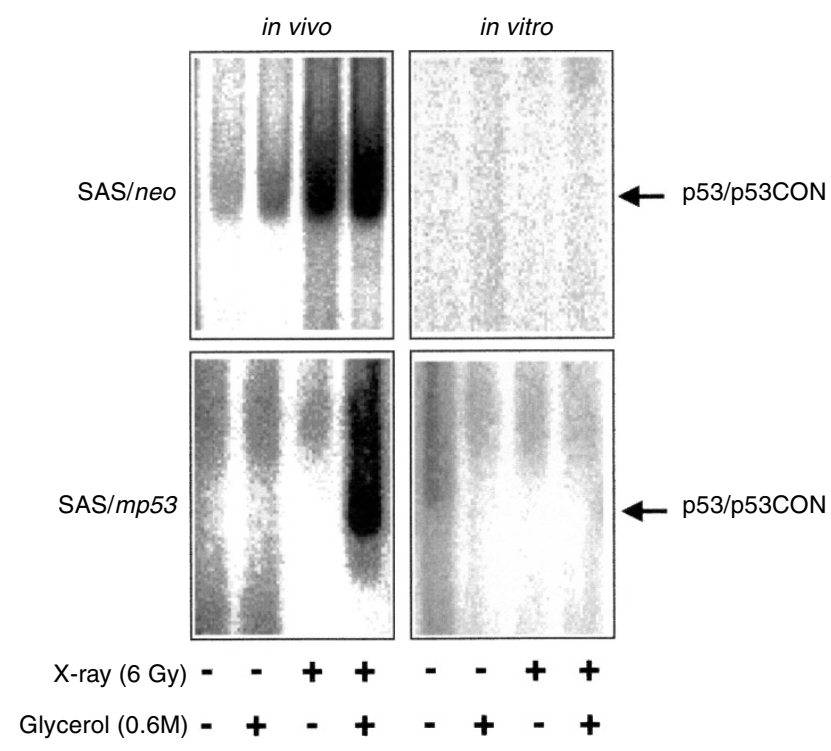

Figure 4 DNA binding activity of nuclear or whole cell extracts from $\mathrm{SAS} /$ neo or SAS/mp53 cells for p53CON. In in vivo sample, the cells were incubated at $37^{\circ} \mathrm{C}$ for $6 \mathrm{~h}$ after glycerol $(0.6 \mathrm{M})$ treatment or X-ray irradiation (6 Gy) combined with or without glycerol. After the incubation, the cells were washed with PBS and harvested for gel mobility-shift assay. In in vitro sample, whole cell extracts from SAS/neo or SAS/mp53 cells were treated with glycerol $(0.6 \mathrm{M})$ or X-ray irradiation (6 Gy) combined with or without glycerol and then incubated for $30 \mathrm{~min}$ at $37^{\circ} \mathrm{C}$. The band position of the specific p53-p53CON complex is shown by arrow

glycerol-treated SAS/mp53 cells was similar to that in SAS/neo cells. We next examined the induction of DNA fragmentation after $\mathrm{X}$-ray irradiation $(6 \mathrm{~Gy})$ using agarose gel electrophoresis of DNA extracted from SAS/neo (Figure 3, lanes 1-5) and SAS/mp53 cells (Figure 3, lanes 7-11). No DNA ladder formation was detected after X-ray irradiation alone in SAS/mp53 cells (Figure 3, upper right panel). However, some DNA ladders in the nucleosomal size range were observed $24-72 \mathrm{~h}$ after X-ray irradiation combined with glycerol $(0.6 \mathrm{M})$ (Figure 3, lower right panel). In contrast, SAS/neo showed the DNA ladders after X-ray irradiation in the absence (Figure 3, upper left panel) or presence (Figure 3, lower left panel) of $0.6 \mathrm{M}$ glycerol. Glycerol alone induced no apoptotic bodies or DNA fragmentation in either type of transformed cells (data not shown). These results showed that the X-ray-induced apoptosis was p53-dependent.

To confirm whether glycerol induces mp53 to adapt the conformation of wtp53, the DNA binding activity of p53 for p53CON was measured in nuclear or whole cell proteins extracted from $\mathrm{SAS} /$ neo or SAS/mp53 cells using the gel mobility-shift assay (Figure 4). Wt p53 is known to bind to p53CON, which is homologous to a specific DNA sequence located upstream of the bax gene and which positively controls apoptosis (Miyashita and Reed, 1995). As supporting the evidence, in in vivo samples, DNA binding activity of nuclear proteins was increased in SAS/neo cells treated with X-ray (6 Gy) combined with or without $0.6 \mathrm{M}$ glycerol (Figure 4). Mp53 can not enhance apoptosis, because most mp53 can not bind to the specific DNA sequence. In fact, in in vivo samples, no DNA binding activity of nuclear proteins was detected in the intact SAS/mp53 cells (Figure 4, lane 1 of in vivo) and this activity level was unchanged even when SAS/mp53 cells were treated with glycerol $(0.6 \mathrm{M})$ or X-rays (6 Gy) (Figure 4, 
lanes 2 and 3 of in vivo). The defective DNA binding ability of p53 from SAS/mp53 cells may be due to the dominant negative nature of this mp53 protein (Kern et al, 1992; Unger et al, 1992). In contrast, when SAS/mp53 cells were treated with glycerol (0.6 M) before X-ray irradiation, nuclear proteins prepared from the cells showed a clear increase of DNA binding activity, probably due to binding of p53 to p53CON (Figure 4 lane 4 of in vivo). When unlabelled $\mathrm{p} 53 \mathrm{CON}$ probe $(\times 100)$ was added to the reaction mixture containing ${ }^{32} \mathrm{P}$-labelled $\mathrm{p} 53 \mathrm{CON}$ and the nuclear proteins from SAS/mp53 cells treated with X-rays combined with glycerol, the binding of $\mathrm{p} 53$ to $\mathrm{p} 53 \mathrm{CON}$ disappeared (data not shown). This indicates that the observed bands are p53-p53CON specific bands. From these results, the apoptosis observed in SAS/mp53 cells (Figures 2 and 3) might be induced through bax gene expression which is up-regulated by the activated $\mathrm{mp} 53$, which underwent a conformational change to wtp53 as reported elsewhere (Brown et al, 1997). The acquisition of binding activity of glycerol-treated mp53 is likely to demand cellular signal transduction induced by $\mathrm{X}$-rays, because no binding activity of p53 was observed when whole cell proteins extracted from intact SAS/neo or SAS/mp53 cells were treated with X-ray (Figure 4, lane 3 of in vitro) or X-ray combined with glycerol (Figure 4, lane 4 of in vitro).

We showed that X-ray or glycerol treatment alone was insufficient to convert the conformation of mp53 to that of active wtp53, because neither treatment led to an increase in the DNA binding activity of p53 (Figure 4). Therefore, we assume that conformational change of mp53 to that of wtp53 induced by glycerol is not sufficient to trigger apoptosis, and some initial signals evoked by $\mathrm{X}$-ray irradiation are required for effective signals leading to apoptosis. Conformation-stabilized p53 produced by glycerol treatment is probably activated through phosphorylation by X-ray-activated protein kinases such as ATM (Banin et al, 1998; Canman et al, 1998; Khanna et al, 1998; Nakagawa et al, 1999), ATR (Tibbetts et al, 1999), PKC (Takenaka et al, 1995) or other kinases (Hall et al, 1996, Jamal and Ziff, 1995). The present results suggest at least that the apoptosis induced by X-rays reported here depends on p53-dependent signal transduction. Glycerol may be generally effective against p53-regulated downstream genes through the restoration of the function of $\mathrm{mp53}$, because restoration of $\mathrm{mp} 53$ function to normal by glycerol is observed in WAF1 induction as well (Ohnishi et al, 1999a).

Possible other explanations can be proposed for the increased DNA binding activity of nuclear extracts from SAS/mp53 cells after combined X-ray and glycerol treatments. Overexpressed mp53 may obtain the ability to enhance the DNA binding activity of endogenous wtp53 due to reactions triggered by the combined treatments. Unknown signal transduction pathways may contribute to the modification of mp53 function.

Some investigators have vigorously searched for molecules which have an ability to induce normal function of $\mathrm{p} 53$ in inactive $\mathrm{p} 53$ or mp53. The latent sequence-specific DNA-binding function is activated by small peptides (Hupp et al, 1995). As already described, glycerol induces conformational change of mp53 to wtp53 (Brown et al, 1997) and restores the ability of mp53 to induce WAF1 expression (Ohnishi, 1999a,b). Similar chaperone-like function has been also found in other molecules such as a synthetic peptide derived from p53 C-terminal domain (Selivanova et al, 1997) and a small compound (Foster et al, 1999). Such manipulation of mp53 or inactive p53 by these molecules may provide new cancer therapies effective for patients carrying $\mathrm{mp} 53$ tumours.

\section{ACKNOWLEDGEMENTS}

This work was supported by Grants-in-Aid from the Ministry of Education, Science, Sports and Culture of Japan.

\section{REFERENCES}

Banin S, Moyal L, Shieh S, Taya Y, Anderson CW, Chessa L, Smorodinsky NI, Prives C, Reiss Y, Shiloh Y and Ziv Y (1998) Enhanced phosphorylation of p53 by ATM in response to DNA damage. Science 281: 1674-1677

Bargonetti J, Friedman PN, Kern SE, Vogelstein B and Prives C (1991) Wild-type but not mutant p53 immunopurified proteins bind to sequences adjacent to the SV40 origin of replication. Cell 65: 1083-1091

Brown CR, Hong-Brown LQ and Welch WJ (1997) Correctiong temperaturesensitive protein folding defects. J Clin Invest 99: 1432-1444

Caelles C, Helmberg A and Karin M (1994) p53-dependent apoptosis in the absence of transcriptional activation of p53-target genes. Nature 370: 220-223

Canman CE, Lim DS, Cimprich KA, Taya Y, Tamai K, Sakaguchi K, Appella E, Kastan MB and Siliciano JD (1998) Activation of the ATM kinase by ionizing radiation and phosphorylation of p53. Science 281: 1677-1679

Dulic V, Kaufmann WK, Wilson SJ, Tlsty TD, Lees E, Harper JW, Elledge SJ and Reed SI (1994) p53-dependent inhibition of cyclin-dependent kinase activities in human fibroblasts during radiation-induced $\mathrm{G}_{1}$ arrest. Cell 76: 1013-1023

El-Deiry WS, Harper JW, O'Connor PM, Velculescu VE, Canman CE, Jackman J, Pietenpol JA, Burrell M, Hill DE, Wang Y, Wilman KG, Mercer WE, Kastan MB, Kohn KW, Elledge SJ, Kinzler KW and Vogelstein B (1994) WAF1/CIP1 is induced in p53-mediated $\mathrm{G}_{1}$ arrest and apoptosis. Cancer Res 54: 1169-1174

Foster BA, Coffey HA, Morin MJ and Rastinejad F (1999) Pharmacological rescue of mutant 553 conformation and function. Science 286: 2507-2510

Hall SR, Campbell LE and Meek DW (1996) Phosphorylation of p53 at the casein kinase II site selectively regulates p53-dependent transcriptional repression but not transactivation. Nucleic Acids Res 24: 1119-1126

Harima Y, Harima K, Shikata N, Oka A, Ohnishi T and Tanaka Y (1998) Bax and $\mathrm{Bcl}-2$ expressions predict response to radiotherapy in human cervical cancer. $J$ Cancer Res Clin Oncol 124: 503-510

Hollstein M, Sidransky D, Vogelstein B and Hallis CC (1991) p53 mutations in human cancers. Science 253: 49-53

Hupp TR, Sparks A and Lane DP (1995) Small peptides activate the latent sequencespecific DNA binding function of p53. Cell 83: 237-245

Jamal S and Ziff EB (1995) Raf phosphorylates p53 in vitro and potentiates p53-dependent transcriptional transactivation in vivo. Oncogene 10: 2095-2101

Jia LQ, Osada M and Ishioka C, Gamo M, Ikawa S, Suzuki T, Shimodaira H, Niitani T, Kudo T, Akiyama M, Kimura N, Matsuo M, Mizusawa H, Tanaka N, Koyama H, Wamba M, Kanamura R and Kuroki T (1997) Screening the p53 status of human cell lines using a yeast functional assay. Mol Carcinog 19 : 243-253

Kern SE, Kinzler KW, Bruskin A, Jarosz D, Friedman P, Prives C and Vogelstein B (1991) Identification of p53 as a sequence-specific DNA-binding protein. Science 252: 1708-1711

Kern SE, Pietenpol JA, Thiagalingam S, Seymour A. Kinzler KW and Vogelstein B (1992) Oncogenic forms of p53 inhibit p53-regulated gene expression. Science 256: $827-830$

Khanna KK, Keating KE, Kozlov S, Scott S, Gatei M, Hobson K, Taya Y, Gabrielli B, Chan D, Lees-Miller SP and Lavin MF (1998) ATM associates with and phosphorylates p53: mapping the region of interaction. Nat Genet 20: 398-400

Miyashita T and Reed JC (1995) Tumor suppressor p53 is a direct transcriptional activator of the human bax gene. Cell 80: 293-299

Nakagawa K, Taya Y, Tamai K and Yamaizumi M (1999) Requirement of ATM in phosphorylation of the human $\mathrm{p} 53$ protein at serine 15 following DNA doublestrand breaks. Mol Cell Biol 19: 2828-2834

Ohnishi T, Wang X, Ohnishi K, Matsumoto H and Takahashi A (1996) p53dependent induction of WAF1 by heat treatment in human glioblastoma cells. J Biol Chem 271: 14510-14513

Ohnishi K, Wang X, Takahashi A and Ohnishi T (1998) Contribution of protein kinase $\mathrm{C}$ to 553 dependent WAF1 induction pathway after heat treatment in human glioblastoma cell lines. Exp Cell Res 238: 399-406

Ohnishi T, Ohnishi K, Wang X, Takahashi A and Okaichi K (1999a) Restoration of mutant TP53 to normal TP53 function by glycerol as a chemical chaperone. Radiat Res 151: 498-500

Ohnishi T, Matsumoto H, Wang X, Takahashi A and Ohnishi K (1999b) Restoration of p53-dependent apoptosis in the cells bearing the mutant $p 53$ gene by glycerol. Int J Radiat Biol 75: 1095-1098 
Selivanova G, Iotsova V, Okan I, Fritsche M, Strom M, Groner B, Grafstrom RC and Wiman KG (1997) Restoration of the growth suppression function of mutant p53 by a synthetic peptide derived from the p53 C-terminal domain. Nat Med 3: $632-638$

Takenaka I, Morin F, Seizinger BR and Kley N (1995) Regulation of the sequencespecific DNA binding function of $\mathrm{p} 53$ by protein kinase $\mathrm{C}$ and protein phosphatases. J Biol Chem 270: 5405-5411

Thomas PJ, Qu BH and Pedersen PL (1995) Defective protein folding as a basis of human disease. TIBS 20: 456-459

Tibbetts RS, Brumbaugh KM, Williams JM, Sarkaria JN, Cliby WA, Shieh SY, Taya Y, Prives C and Abraham RT (1999) A role for ATR in the DNA damage-induced phosphorylation of p53. Genes Dev 13: 152-157
Unger T, Nau MM, Segal S and Minna JD (1992) p53: a transdominant regulator of transcription whose function is ablated by mutations occurring in human cancer. $E M B O J$ J1: 1383-1390

Waga S, Hannon GJ, Beach D and Stillman B (1994) The p21 inhibitor of cyclindependent kinases controls DNA replication by interaction with PCNA. Nature 369: 574-577

Welch WJ and Brown CR (1996) Influence of molecular and chemical chaperones on protein folding. Cell Stress Chap 1: 109-115 